\title{
Hubungan Tingkat Pengetahuan Dan Status Pekerjaan Dengan Pemberian Asi Eksklusif
}

\section{Nurul Septyasrini ${ }^{1}$, Faizah Betty Rahayuningsih ${ }^{2 *}$}

${ }^{1}$ Program Studi Ilmu Keperawatan Universitas Muhammadiyah Surakarta, Kartasura, 57162, Jawa Tengah, Indonesia.

${ }^{2}$ Departemen Keperawatan Maternitas, Program Studi Ilmu Keperawatan Universitas Muhammadiyah Surakarta, Kartasura, 57162, Jawa Tengah, Indonesia.

*Korespondensi: faizahbetty@ymail.com

\begin{abstract}
Abstrak: Masa bayi dan balita menjadi masa yang baik bagi pertumbuhan anak. Pemberian nutrisi yang sesuai menjadi kewajiban ibu dan keluarga untuk mendukung pertumbuhan anak. Gizi yang paling tepat diberikan kepada bayi adalah ASI (Air Susu Ibu). Pemberian ASI Eksklusif kepada bayi 06 bulan telah direkomendasikan oleh WHO (World Health Organization), UNICEF (United Nation Childrens Fund), serta Depkes RI (Departemen Kesehatan Republik Indonesia). Namun sayangnya presentase pemberian ASI ekslusif di Indonesia masih belum memenuhi target yang diinginkan, yaitu sebesar $54,3 \%$ dengan target yang dinginkan sebesar $75 \%$. Tingkat pengetahuan dan status pekerjaan ibu merupakan faktor yang mempengaruhi pemberian ASI eksklusif karena masih kurangnya pemahaman ibu tentang praktik pemberian ASI eksklusif serta kesibukan ibu karena pekerjaannya. Oleh karena itu, tujuan dari penelitian ini adalah untuk mengetahui hubungan antara tingkat pengetahuan dan status pekerjaan dengan pemberian ASI eksklusif. Penelitian ini menggunakan jenis penelitian kuantitatif dengan metode penelitian correlasional. Rancangan penelitian yang digunakan adalah cross sectional. Sampel pada penelitian ini adalah ibu yang mempunyai bayi berusia 6 bulan. Teknik pegambilan sampel yang digunakan adalah total populasi dan didapatkan sejumlah 31 responden. Hasil penelitian menunjukkan bahwa ada hubungan antara tingkat pengetahuan dengan pemberian ASI ekslusif, nilai $p=0,022$. Ada hubungan antara status pekerjaan dengan pemberian ASI eksklusif, nilai $p=0,023$.
\end{abstract}

Kata kunci: ASI eksklusif, tingkat pengetahuan, status pekerjaan

Abstract: Infancy and toddler be a good time for growing children. The provision of adequate nutrition into maternal and family obligations to support the growth of children. Nutrition is the most appropriate given to babies is breast milk. Exclusive breastfeeding for infants 0-6 months has been recommended by the WHO (World Health Organization), UNICEF (United Nation Childrens Fund), and Depkes RI (Departemen Kesehatan Republik Indonesia). But unfortunately the percentage of exclusive breastfeeding in Indonesia still does not meet the desired target, amounting to $54.3 \%$ with a target desired by $75 \%$. The level of knowledge and maternal employment status is a factor affecting exclusive breastfeeding for the mother is still a lack of understanding about the practice of exclusive breastfeeding and busy mother because of her job. Therefore, the purpose of this study was to determine the relationship between level of knowledge and employment status with exclusive breastfeeding. This study used a quantitative research with research methods correlational. The study design used is cross sectional. Samples are mothers with babies aged 6 months. The sampling technique used the total population and obtained a number of 31 respondents. The results showed that there was a relationship between the level of knowledge with exclusive breastfeeding, the value of $p=0.022$. There is a relationship between employment status with exclusive breastfeeding, the value of $p=0.023$.

Key words: exclusive breastfeeding, level of knowledge, employment status 


\section{PENDAHULUAN}

Departemen Kesehatan Republik Indonesia dan United Nation Childrens Fund (UNICEF), telah merekomendasikan pemberian ASI eksklusif pada bayi sampai usia mencapai 4 atau 6 bulan. Dalam perkembangannya, pemberian ASI eksklusif sampai bayi berusia 6 bulan dinilai memberikan hasil yang lebih baik. Keputusan Menteri Kesehatan (Kepmenkes) No. 450/2003, juga merekomendasikan tentang pemberian ASI eksklusif pada bayi sampai usia 6 bulan (Riksani, 2012).

Masa pertumbuhan yang pesat terjadi pada masa bayi dan balita. Oleh karena itu, pada masa ini diperlukan gizi yang baik dan mencukupi untuk bayi (Marmi \& Raharjo, 2012). Gizi yang paling tepat diberikan kepada bayi adalah ASI (Air Susu Ibu). Pemberian ASI eksklusif pada bayi usia 0-6 bulan mempunyai manfaat yang sangat beragam.

Menurut WHO (World Health Organization), ASI eksklusif yaitu memberikan ASI pada bayi sampai berusia 6 bulan tanpa memberikan tambahan makanan atau cairan lainnya. ASI merupakan makanan terbaik bagi tumbuh kembang bayi. Kandungan gizi yang terdapat dalam ASI sangat sempurna dan bermanfaat bagi bayi (Maritalia, 2012). Walaupun kebijakan pemberian ASI eksklusif sudah dikeluarkan, menurut data WHO tahun 2012, Indonesia berada di rangking 42 mengenai Infans Exclusively Breastfed for The First 6 Months of Life. Menurut data Kementerian Kesehatan RI (Kemenkes RI, 2014) presentase nasional cakupan pemberian ASI eksklusif tahun 2013 yaitu sebesar 54,3\%. Angka tersebut masih dibawah target yang ditentukan yaitu sebesar $75 \%$.

Menurut catatan dari Dinas Kesehatan Provinsi Jawa Tengah (Dinkes Jateng, 2014) di provinsi Jawa Tengah pada tahun 2014 presentase pemberian ASI eksklusif pada bayi 0-6 bulan sebesar 60,7\%. Di Kabupaten Boyolali presentase pemberian ASI eksklusif sebesar 58,1\%. Pemberian ASI eksklusif ini dipengaruhi oleh berbagai permasalahan antara lain yaitu gencarnya pemasaran susu formula untuk bayi $0-6$ bulan serta tidak ada masalah medis berkaitan pemberian susu formula, banyaknya perusahaan yang mempekerjakan wanita dan tidak memberi peluang ibu yang mempunyai bayi 0-6 bulan untuk memberikan ASI eksklusif, belum banyak kesadaran dari tenaga kesehatan untuk mengkampanyekan pemberian ASI eksklusif justru mendorong untuk memberikan susu formula, kurangnya tenaga konselor perihal ASI, dan belum maksimalnya edukasi, sosialisasi advokasi, dan kampanye pemberian ASI.

Menurut penelitian yang dilakukan oleh Fikawati dan Syafiq (2009) tentang penyebab keberhasilan dan kegagalan praktik pemberian ASI eksklusif diperoleh hasil bahwa pendidikan, pengetahuan, pengalaman ibu, IMD, dan dukungan tenaga kesehatan penolong persalinan mempunyai efek positif terhadap pemberian ASI eksklusif, sedangkan iklan susu formula mempunyai efek negatif terhadap pemberian ASI eksklusif.

Masih kurangnya pengetahuan ibu dan alasan pekerjaan menjadi faktor yang mempengaruhi pemberian ASI eksklusif. Menurut Dagun dalam Astutik (2014), masih ada ibu yang kurang mengetahui dan memahami cara menyusui yang benar itu seperti apa. Selain itu ibu kurang memahami pentingnya pemberian ASI dan cara pemberian ASI bila ibu diharuskan berpisah dengan bayinya.

Berdasarkan studi pendahuluan yang telah dilakukan oleh peneliti, di Puskesmas Banyudono 1 Boyolali cakupan pemberian ASI eksklusif masih tergolong rendah (Dinkes Boyolali, 2014). Setelah dilakukan studi lebih lanjut alasan kenapa ibu jarang bahkan tidak memberikan ASI eksklusif kepada bayinya adalah karena produksi ASI yang hanya keluar sedikit serta kurangnya pengetahuan ibu tentang pemberian ASI eksklusif, sehingga ibu memilih memberikan susu formula kepada bayinya. Selain itu, tuntutan ekonomi yang dihadapi oleh keluarga yang mengharuskan ibu untuk bekerja, membuat ibu lebih memilih menitipkan bayinya kepada orang lain, seperti pada ibu/ mertua. Ketika bayi sedang diasuh oleh orang lain, sebagian besar akan memberikan susu formula sebagai makanan si bayi.

Selain berdasar pada studi pendahuluan diatas, dari beberapa jurnal yang telah peneliti baca mengenai hubungan tingkat pendidikan dan status pekerjaan terhadap pemberian ASI eksklusif, terdapat perbedaan pada hasil penelitian. Pada penelitian Satino dan Setyorini (2014) didapatkan hasil 
yaitu faktor pekerjaan dan pengetahuan mempengaruhi pemberian ASI eksklusif. Sedangkan pada penelitian Mamonto (2015) didapatkan hasil yang berkebalikan yaitu faktor pekerjaan dan pengetahuan tidak ada hubungannya dengan pemberian ASI eksklusif. Oleh karena itu, berdasarkan uraian latar belakang diatas, peneliti tertarik untuk meneliti tentang Hubungan antara Tingkat Pengetahuan dan Status Pekerjaan dengan Pemberian ASI Eksklusif di Wilayah Kerja Puskesmas Banyudono 1 Boyolali.

\section{METODE}

Pada penelitian ini menggunakan jenis penelitian kuantitatif, dengan metode penelitian Correlasional yaitu menghubungkan dua variabel atau lebih pada suatu situasi atau sekelompok subjek tertentu untuk mengetahui hubungan diantara variabel-variabel tersebut (Notoatmodjo, 2010). Rancangan penelitian menggunakan pendekatan Cross Sectional dimana pengamatan dan pengumpulan data dilakukan sekali pada waktu penelitian. Penelitian ini dilakukan di wilayah kerja Puskesmas Banyudono 1 Boyolali pada bulan April - Mei 2016.

Populasi adalah keseluruhan subjek penelitian yang akan mendapat dampak dari generalisasi hasil penelitian (Arikunto dalam Sumantri, 2011). Populasi dalam penelitian ini adalah seluruh ibu yang memiliki bayi berusia 6 bulan pada April 2016 yang berada di wilayah kerja Puskesmas Banyudono 1 Boyolali. Dari data puskesmas didapatkan sejumlah 31 ibu yang memiliki bayi berusia 6 bulan pada April 2016 sebagai populasi penelitian.

Sampel merupakan bagian dari populasi yang memiliki karakteristik, sehingga dapat diselidiki dan diukur (Sumantri, 2011). Pada penelitian ini, teknik pengambilan sampel yang digunakan adalah total populasi atau sampling jenuh yaitu semua populasi yang ada diambil dan dijadikan sampel penelitian (Hidayat, 2008). Jadi, sampel penelitian ini adalah ibu yang memiliki bayi berusia 6 bulan pada April 2016 yang berada di wilayah kerja Puskesmas Banyudono 1 Boyolali dengan jumlah populasi sebanyak 31 orang.

HASIL

Tabel 1. Distribusi Frekuensi Responden Berdasarkan Usia Ibu

\begin{tabular}{ccc}
\hline Usia Ibu & Jumlah & $\mathbf{( \% )}$ \\
\hline $15-25$ tahun & 18 & $58,1 \%$ \\
$26-34$ tahun & 13 & $41,9 \%$ \\
\hline Total & 31 & $100 \%$ \\
\hline
\end{tabular}

Pada tabel 1 diatas, dapat diketahui bahwa sebagian besar ibu berusia 15 - 25 tahun yaitu sebanyak 18 responden $(58,1 \%)$ dan sisanya berusia 26 - 34 tahun yaitu sebanyak 13 responden $(41,9 \%)$. Ibu yang berusia 15 - 25 tahun mempunyai presentase yang lebih banyak daripada ibu berusia $26-34$ tahun, dengan demikian usia ibu yang memiliki bayi 6 bulan di wilayah kerja Puskesmas Banyudono 1 Boyolali sebagian besar adalah ibu usia muda.

Tabel 2. Distribusi Frekuensi Responden Berdasarkan Pendidikan Ibu

\begin{tabular}{ccc}
\hline Pendidikan Ibu & Jumlah & $\mathbf{( \% )}$ \\
\hline SD & 2 & $6,5 \%$ \\
SMP & 10 & $32,3 \%$ \\
SMA & 14 & $45,2 \%$ \\
Perguruan Tinggi & 5 & $16,1 \%$ \\
\hline Total & 31 & $100 \%$ \\
\hline
\end{tabular}

Berdasarkan tabel 2 diatas dapat diketahui bahwa sebagian besar pendidikan ibu adalah SMA sejumlah 14 responden $(45,2 \%), 10$ responden $(32,3 \%)$ berpendidikan SMP, 5 responden $(16,1 \%)$ 
berpendidikan perguruan tinggi, dan sisanya 2 responden (6,5\%) berpendidikan SD. Tingkat pendidikan ibu yang memiliki bayi 6 bulan di wilayah kerja Puskesmas Banyudono 1 Boyolali sebagian besar adalah SMA.

Tabel 3. Distribusi Frekuensi Berdasarkan Paritas

\begin{tabular}{lll}
\hline Paritas & Jumlah & (\%) \\
\hline Anak pertama & 16 & $51,6 \%$ \\
Anak kedua & 14 & $45,2 \%$ \\
Anak ketiga & 1 & $3,2 \%$ \\
\hline Total & 31 & $100 \%$ \\
\hline
\end{tabular}

Berdasarkan tabel 3 diketahui bahwa sebagian besar responden merupakan ibu yang memiliki anak pertama yaitu sebanyak 16 responden (51,6\%), sisanya yaitu 14 responden (45,2\%) merupakan ibu yang memiliki anak kedua dan 1 responden $(3,2 \%)$ merupakan ibu yang memiliki anak ketiga.

Tabel 4. Distribusi Frekuensi Tingkat Pengetahuan

\begin{tabular}{lll}
\hline Tingkat Pengetahuan & Jumlah & $\mathbf{( \% )}$ \\
\hline Rendah & 17 & $54,8 \%$ \\
Tinggi & 14 & $45,2 \%$ \\
\hline Total & 31 & $100 \%$ \\
\hline
\end{tabular}

Berdasarkan tabel 4 dapat diketahui bahwa sebanyak 17 responden $(54,8 \%)$ memiliki tingkat pengetahuan rendah dan sebanyak 14 responden (45,2\%) memiliki tingkat pengetahuan tinggi.

Tabel 5. Distribusi Frekuensi Status Pekerjaan

\begin{tabular}{|c|c|c|}
\hline Status Pekerjaan & Jumlah & $(\%)$ \\
\hline Bekerja & 12 & $38,7 \%$ \\
\hline Ibu rumah & 19 & $61,3 \%$ \\
\hline Total & 31 & $100 \%$ \\
\hline
\end{tabular}

Berdasarkan tabel 5 diatas diperoleh hasil sebanyak 12 responden (38,7\%) status pekerjaan ibu selama masa menyusui 6 bulan adalah bekerja dan sebanyak 19 responden $(61,3 \%)$ status pekerjaan ibu selama masa menyusui 6 bulan adalah ibu rumah tangga.

Tabel 6. Distribusi Frekuensi Pemberian ASI Eksklusif

\begin{tabular}{ccc}
\hline Pemberian ASI Eksklusif & Jumlah & (\%) \\
\hline $\begin{array}{c}\text { Diberikan ASI, makanan serta } \\
\text { cairan lain selama 6 bulan } \\
\text { Diberikan ASI saja selama 6 bulan }\end{array}$ & 18 & $58,1 \%$ \\
\hline Total & 13 & $41,9 \%$ \\
\hline
\end{tabular}

Berdasarkan tabel 6 diatas diperoleh hasil bahwa sebanyak 18 responden (58,1\%) memberikan ASI dan makanan lain kepada bayi dan sebanyak 13 responden $(41,9 \%)$ memberikan ASI saja kepada bayi. 
Tabel 7. Tabulasi Silang Tingkat Pengetahuan dengan Pemberian ASI Ekslusif

\begin{tabular}{cccccccc}
\hline & \multicolumn{2}{c}{$\begin{array}{c}\text { Diberi ASI, } \\
\text { makanan \& cairan } \\
\text { lain selama } 6 \\
\text { Bulan }\end{array}$} & $\begin{array}{c}\text { Diberikan ASI saja } \\
\text { selama 6 bulan }\end{array}$ & \multicolumn{2}{c}{ Total } \\
\hline Tingkat & Rendah & 13 & $76,5 \%$ & 4 & $23,5 \%$ & 17 & $100 \%$ \\
Pengetahuan & Tinggi & 5 & $35,7 \%$ & 9 & $64,3 \%$ & 14 & $100 \%$ \\
Jumlah & 18 & $58,1 \%$ & 13 & $41,9 \%$ & 31 & $100 \%$ \\
\hline
\end{tabular}

$x^{2}$ Hitung $=5,237$

$P$ value $=0,022$

Kesimpulan $=\mathrm{H}_{0}$ ditolak

Tabulasi data antara tingkat pengetahuan dengan pemberian ASI eksklusif menunjukkan adanya penurunan pemberian ASI eksklusif seiring dengan menurunnya pengetahuan ibu. Hal tersebut terlihat pada tingkat pengetahuan rendah terdapat 13 responden $(76,5 \%)$ yang memberikan ASI, makanan serta cairan lain kepada bayi dan pada tingkat pengetahuan tinggi terdapat 5 responden $(35,7 \%)$ yang memberikan ASI, makanan serta cairan lain kepada bayi. Hal tersebut didukung oleh hasil tabulasi pada tingkat pengetahuan rendah terdapat 4 responden $(23,5 \%)$ yang memberikan ASI saja kepada bayinya dan pada tingkat pengetahuan tinggi terdapat 9 responden $(64,3 \%)$ yang memberikan ASI saja kepada bayi.

Berdasarkan hasil analisis menggunakan chi square hubungan tingkat pengetahuan dengan pemberian ASI eksklusif diperoleh nilai sebesar 5,237 dengan nilai signifikansi ( $p$-value) sebesar 0,022 $(<0,05)$ dan kesimpulan yang diperoleh adalah $\mathrm{H}_{0}$ ditolak. Selanjutnya, interpretasi dari hasil uji tersebut adalah ada hubungan antara tingkat pengetahuan dengan pemberian ASI eksklusif di wilayah kerja Puskesmas Banyudono 1 Boyolali, dimana hubungan tersebut terdapat korelasi positif yang signifikan, hal itu dapat dilihat bahwa semakin rendah tingkat pengetahuan ibu semakin sedikit pula ibu yang memberikan ASI eksklusif yaitu 4 responden $(23,5 \%)$.

Tabel 8. Tabulasi Silang Status Pekerjaan dengan Pemberian ASI Eksklusif

\begin{tabular}{|c|c|c|c|c|c|c|c|}
\hline & & \multicolumn{2}{|c|}{$\begin{array}{c}\text { Diberikan ASI, } \\
\text { makanan \& cairan } \\
\text { lain selama } 6 \text { bulan }\end{array}$} & \multicolumn{2}{|c|}{$\begin{array}{l}\text { Diberikan ASI saja } \\
\text { selama } 6 \text { bulan }\end{array}$} & \multicolumn{2}{|c|}{ Total } \\
\hline & & Frek & $\%$ & Frek & $\%$ & Frek & $\%$ \\
\hline \multirow[t]{2}{*}{ Status Pekerjaan } & Bekerja & 10 & $83,3 \%$ & 2 & $16,7 \%$ & 12 & $100 \%$ \\
\hline & $\begin{array}{l}\text { Ibu rumah } \\
\text { tangga }\end{array}$ & 8 & $42,1 \%$ & 11 & $57,9 \%$ & 19 & $100 \%$ \\
\hline Jumlah & & 18 & $58,1 \%$ & 13 & $41,9 \%$ & 31 & $100 \%$ \\
\hline
\end{tabular}

$x^{2}$ Hitung $=5,134$

$\mathrm{P}$ value $=0,023$

Kesimpulan $=\mathrm{H}_{0}$ ditolak

Tabulasi data status pekerjaan dengan pemberian ASI eksklusif menunjukkan adanya penurunan pemberian ASI eksklusif seiring dengan meningkatnya status pekerjaan ibu. Hal tersebut terlihat pada status pekerjaan ibu bekerja sebanyak 10 responden (83,3\%) memberikan ASI, makanan serta cairan lain kepada bayi dan sebanyak 2 responden (16,7\%) memberikan ASI saja pada bayinya. Pada status pekerjaan ibu rumah tangga sebanyak 8 responden $(42,1 \%)$ memberikan ASI, makanan serta cairan lain kepada bayi dan sebanyak 11 responden (57,9\%) memberikan ASI saja kepada bayi.

Berdasarkan hasil analisis chi square hubungan antara status pekerjaan dengan pemberian ASI 
eksklusif diperoleh nilai $\chi^{2}$ sebesar 5,134 dengan nilai signifikansi ( $p$-value) sebesar 0,023 $(<0,05)$ dan kesimpulan yang diperoleh adalah $\mathrm{H}_{0}$ ditolak. Maka, interpretasi dari analisa ini adalah ada hubungan antara status pekerjaan dengan pemberian ASI eksklusif di wilayah kerja Puskesmas Banyudono 1 Boyolali, dimana hubungan tersebut terdapat korelasi negatif yang signifikan, hal itu dapat dilihat bahwa semakin sibuk ibu dalam bekerja semakin sedikit ibu yang memberikan ASI eksklusif.

\section{PEMBAHASAN}

\section{Distribusi Frekuensi Responden Berdasarkan Usia Ibu}

Menurut Maritalia (2012) ibu yang berusia muda, kesiapan dan kemampuan dalam menghadapi masa nifas dan menyusui akan berbeda dengan ibu yang berusia lebih tua. Menurut Naanyu (2008) ibu yang berusia lebih tua mempunyai durasi yang lebih lama ketika memberikan ASI eksklusif dibandingkan ibu usia muda. Perbedaan ini muncul dikarenakan adanya perbedaan pengalaman hidup seseorang.

\section{Distribusi Frekuensi Responden Berdasarkan Pendidikan Ibu}

Menurut Notoadmodjo (2010) perilaku seseorang dipengaruhi oleh pendidikannya, semakin tinggi tingkat pendidikan yang dimiliki maka informasi yang diperoleh akan semakin mudah.

\section{Distribusi Frekuensi Berdasarkan Paritas}

Sebagian besar responden merupakan ibu primipara (pertama kali melahirkan). Menurut Maritalia (2012) terdapat perbedaan dalam menghadapi persalinan dan masa nifas antara ibu primipara dan ibu multipara. Karena baru pertama melahirkan, ibu primipara belum memiliki pengalaman menyusui sebelumnya, sehingga dalam praktik pemberian ASI eksklusif akan mengalami kesulitan dan pemberian tidak maksimal. Menurut Guyton dalam Mudzengerere dan Mudzengerere (2013) kegagalan ibu dalam memberikan ASI eksklusif dalam minggu-minggu awal menyusui dapat mempengaruhi tindakannya dalam pemberian makanan lain selain ASI. Hal ini lebih sering terjadi pada ibu yang baru pertama melahirkan karena teknik menyusui yang masih buruk.

\section{Distribusi Frekuensi Tingkat Pengetahuan}

Sebagian besar responden memiliki tingkat pengetahuan tentang ASI eksklusif yang masih rendah, menurut Uchenne (2012) hal tersebut dikarenakan mereka masih belum seluruhnya paham tentang ASI eksklusif itu sendiri sehingga pada praktik pemberian ASI eksklusifnyapun juga belum maksimal. Menurut Iliff, dkk dalam Mudzengerere dan Mudzengerere (2013) pengetahuan ibu mempunyai peranan yang penting dalam pemberian ASI eksklusif. Informasi yang adekuat tentang ASI eksklusif diberikan saat periode antenatal dan post natal tetapi ketika di rumah, ibu mengalami kesulitan dalam mengambil keputusan. Hal ini dikarenakan adanya faktor sosio-kultural yang masih kuat di lingkungan tempat tinggal ibu sehingga mempengaruhi pengambilan keputusan dalam pemberian ASI eksklusif.

\section{Distribusi Frekuensi Status Pekerjaan}

Menurut Danso (2014) ibu yang bekerja mengalami kesulitan dalam memberikan ASI eksklusif karena harus membagi waktu dengan pekerjaannya, selain itu pengaruh dari anggota keluarga juga mempengaruhi praktik pemberian ASI eksklusif. Menurut Uchenna (2012), perusahaan tempat ibu bekerja juga mempunyai peranan yang besar dalam memberikan support tercapainya pemberian ASI eksklusif, hal ini dikarenakan ibu harus kembali bekerja $<6$ bulan setelah masa kelahiran bayi (sekitar 3 bulan). Keharusan ibu untuk kembali bekerja, menjadi alasan untuk tidak melanjutkan memberikan ASI eksklusif (Galson dalam Uchenna, 2012). 


\section{Distribusi Frekuensi Pemberian ASI Eksklusif}

Menurut Khanal, dkk (2014) faktor yang mempengaruhi pemberian ASI eksklusif antara lain yaitu karakteristik ibu (pendidikan, pekerjaan, kondisi kesehatan, usia), karakteristik bayi (jenis kelamin, urutan kelahiran, penyakit), dan praktik budaya (awal menyusui, waktu pemberian makanan lain). Dalam penelitian Satino dan Setyorini (2014) faktor yang mempengaruhi pemberian ASI eksklusif pada ibu primipara antara lain yaitu usia, pendidikan, pengetahuan, pekerjaan, perilaku, dan lingkungan.

\section{Hubungan Tingkat Pengetahuan dengan Pemberian ASI Ekslusif}

Rendahnya tingkat pengetahuan ibu dan sedikitnya jumlah ibu yang memberikan ASI eksklusif sesuai dengan yang dikemukakan oleh Notoatmodjo (2007) bahwa pengetahuan merupakan hasil tahu dan hal ini terjadi setelah dilakukan pengindraan terhadap suatu objek tersebut. Menurut Suhartono (2011) pengetahuan seseorang diperoleh dari beberapa sumber yaitu adanya kepercayaan dari tradisi, adat, dan agama. Pada penelitian ini rendahnya tingkat pengetahuan ibu dipengaruhi oleh berbagai faktor seperti kepercayaan yang salah, kurangnya pengalaman menyusui karena kebanyakan responden merupakan ibu primipara, dan pengaruh dari iklan susu formula.

Kepercayaan yang ternyata salah dan telah diyakini sekian lama akan sulit untuk diubah begitu saja. Pengalaman juga menjadi sumber pengetahuan seseorang. Ibu yang telah mempunyai pengalaman menyusui sebelumnya cenderung lebih memahami tentang manfaat praktik pemberian ASI eksklusif (Suryaningtyas dan Ambarwati, 2004). Pada sebagian kelompok masyarakat, pemberian ASI belum sepenuhnya dimanfaatkan bahkan terjadi kecenderungan pergeseran pemilihan pemberian susu formula daripada ASI (Syahdrajat dalam Aziezah dan Adriani, 2013).

Kondisi ibu seperti air susu yang susah keluar dan ibu yang juga harus bekerja, juga mempengaruhi dalam pemberian ASI eksklusif. Kondisi ibu itulah yang mendorong ibu untuk memilih memberikan susu formula, karena bagaimanapun juga asupan nutrisi bayi harus tetap diberikan. Bagi ibu yang bekerja walaupun tingkat pengetahuannya tinggi, ia terpaksa memilih untuk memberikan susu formula dikarenakan waktu yang banyak dihabiskan untuk pekerjaannya. Pada awal menyusui, ibu masih bisa memberikan ASI ekslusif, namun ketika saat cuti ibu berakhir dan mengharuskan ibu untuk kembali bekerja, memberikan susu formula kepada bayi menjadi pilihan ibu.

Pada penelitian ini, juga didapatkan hasil bahwa 4 responden $(23,5 \%)$ ibu berpengetahuan rendah dapat memberikan ASI eksklusif. Ibu mengaku bahwa ia mendapat anjuran dari orang tua, saudara dekat, dan teman dekat mereka bahwa sebaik-baiknya makanan untuk bayi tidak ada yang lebih baik daripada susu dari ibunya sendiri. Itulah yang menjadi alasan ibu untuk lebih memilih memberikan ASI eksklusif. Menurut Suryaningtyas dan Ambarwati (2004), pengetahuan juga dapat diperoleh secara turun menurun dari orang tua. Pengetahuan yang orang tua miliki akan mereka bagikan kepada anak mereka. Menurut Suhartono (2011), pengetahuan juga dapat bersumber dari kesaksian orang lain. Manusia cenderung mempercayai manusia lain yang mereka percayai/ dihormati/ dituakan.

Berdasarkan penelitian yang terdahulu yaitu penelitian Rachmaniah (2014) tentang Hubungan Tingkat Pengetahuan Ibu tentang ASI dengan Tindakan ASI Eksklusif, diperoleh hasil bahwa terdapat hubungan yang bermakna antara tingkat pengetahuan ibu tentang ASI dengan tindakan ASI eksklusif. Semakin tinggi tingkat pengetahuan seseorang tentang ASI maka akan mempengaruhi pola pikir dan sikap seseorang sehingga akan menimbulkan perilaku positif memberikan ASI eksklusif.

\section{Hubungan Status Pekerjaan dengan Pemberian ASI Eksklusif}

Hubungan Status Pekerjaan dengan Pemberian ASI Eksklusif ini memperoleh hasil yang sama dengan penelitian Dahlan, dkk (2013). Apabila status ibu adalah bekerja maka besar kemungkinan bagi ibu untuk tidak memberikan ASI eksklusif, hal itu dikarenakan banyak waktu yang ibu habiskan untuk pekerjaannya. Namun sebaliknya bila status ibu adalah tidak bekerja maka besar kemungkinan bagi ibu untuk memberikan ASI eksklusif, karena banyak waktu luang ibu yang dapat digunakan untuk merawat dan memberikan kasih sayang untuk bayinya. 
Tingginya jumlah ibu bekerja yang tidak memberikan ASI eksklusif dikarenakan mereka merasa tidak mempunyai waktu untuk memberikan ASI eksklusif. Selain itu, maraknya iklan susu formula yang menyajikan penawaran yang menarik dan meyakinkan serta tersedianya susu formula yang mudah didapat juga menjadi alasan ibu untuk tidak memberikan ASI eksklusif dan beralih menggunakan susu formula. Pemilihan penggunakan susu formula karena iklan yang menarik ternyata tidak hanya berlaku bagi ibu yang bekerja saja namun juga berlaku pada ibu rumah tangga. Sebanyak 8 responden $(25,81 \%)$ ibu rumah tangga juga memberikan ASI dan makanan serta cairan lain kepada bayinya, diantaranya yaitu susu formula.

Rendahnya tingkat pengetahuan yang ibu miliki juga dapat mempengaruhi pemberian ASI ekslusif, baik bagi ibu yang bekerja maupun ibu rumah tangga. Menurut Maritalia (2012), alasan tidak memberikan ASI kepada bayi karena kesibukannya dalam bekerja merupakan alasan yang tidak benar. Padahal sebenarnya, walaupun ibu sibuk dalam pekerjaannya, pemberian ASI eksklusif kepada bayi masih bisa dilakukan yaitu dengan cara memompa atau memerah ASI dan selanjutnya ASI disimpan untuk diberikan kepada bayi ketika ibu bekerja. Hal inilah yang masih belum ketahui oleh ibu, namun pada penelitian ini terdapat 2 responden (6,45\%) yang sudah mempraktekkan pemberian ASI ekslusif dengan cara memompa dan menyimpannya di lemari pendingin.

Okawary (2015) dalam penelitiannya yang berjudul Hubungan Status Pekerjaan Ibu dengan Pemberian ASI Eksklusif di Wilayah Kerja Puskesmas Seyegan Sleman Yogyakarta, diperoleh hasil bahwa ada hubungan yang signifikan antara status pekerjaan dengan pemberian ASI eksklusif di wilayah kerja Puskesmas Seyegan Sleman Yogyakarta. Pada penelitian Okawary, menunjukkan adanya hubungan yang kuat antara status pekerjaan ibu dengan pemberian ASI eksklusif di wilayah kerja Puskesmas Seyegan Sleman Yogyakarta.

\section{KESIMPULAN}

Tingkat pengetahuan ibu tentang ASI eksklusif di wilayah kerja Puskesmas Banyudono 1 Boyolali sebagian besar masih rendah. Sebagian besar ibu yang mempunyai bayi 6 bulan di wilayah kerja Puskesmas Banyudono 1 Boyolali status pekerjaannya adalah ibu rumah tangga dan sisanya adalah ibu yang bekerja. Pemberian ASI eksklusif di wilayah kerja Puskesmas Banyudono 1 Boyolali lebih sedikit dibandingkan dengan pemberian ASI, makanan serta cairan lain kepada bayi. Terdapat hubungan antara tingkat pengetahuan dengan pemberian ASI eksklusif di wilayah kerja Puskesmas Banyudono 1 Boyolali. Terdapat hubungan antara status pekerjaan dengan pemberian ASI eksklusif di wilayah kerja Puskesmas Banyudono 1 Boyolali.

Hasil penelitian dapat dijadikan tambahan informasi bagi ibu dan keluarga, khususnya bagi ibu yang berada dalam masa menyusui maupun yang akan masuk pada masa menyusui. Pentingnya menambah pengetahuan tentang pemberian ASI eksklusif, merupakan salah satu cara untuk memenuhi asupan nutrisi bayi dan mempererat kasih sayang antara bayi, ibu, dan keluarga. Hasil penelitian ini dapat dijadikan pertimbangan bagi tempat pelayanan kesehatan setempat, baik posyandu maupun puskesmas bahwa tingkat pengetahuan ibu dan pemberian ASI eksklusifnya masih rendah. Status ibu yang bekerja juga menjadi alasan ibu untuk tidak memberikan ASI eksklusif.

Tempat pelayanan kesehatan hendaknya melakukan upaya untuk meningkatkan pengetahuan ibu tentang pentingnya pemberian ASI eksklusif dan mengubah persepsi ibu bahwa bekerja bukanlah hambatan untuk memberikan ASI eksklusif. Memberikan edukasi kepada ibu, dapat menjadi salah satu upaya dalam meningkatkan pengetahuan ibu sehingga pengetahuan ibu meningkat, persepsi salah ibu dapat diluruskan, dan pemberian ASI eksklusif dapat berjalan maksimal. Bagi peneliti yang akan datang hendaknya menambahkan faktor lain yang mempengaruhi pemberian ASI eksklusif. Sehingga, diharapkan dapat ditemukan suatu kesimpulan faktor apa yang paling mempengaruhi pemberian ASI eksklusif.

\section{DAFTAR PUSTAKA}

Astutik, R. Y. (2014). Payudara dan Laktasi. Jakarta: Salemba Medika. 
Aziezah, N., \& Adriani, M. (2013). Perbedaan Tingkat Konsumsi dan Status Gizi antara Bayi dengan Pemberian ASI Eksklusif dan Non ASI Eksklusif. Media Gizi Indonesia, 9(1), 78-83.

Azwar, S. (2010). Sikap Manusia Teori dan Pengukurannya. Yogyakarta: Pustaka Belajar.

Dahlan, S. (2011). Penelitian Prognosis dan Sistem Skoring: Disertai Praktik dengan SPSS dan Stata. Sumedang: ALQA Prisma Interdelta Jatinangor.

Danso, J. (2014). Examining the Practice of Exclusive Breastfeeding among Professional Working Mothers in Kumasi Metropolis of Ghana. Internasional Journal of Nursing, 1(1), 11-24.

Dinas Kesehatan Jateng. (2014). Profil Kesehatan Provinsi Jawa Tengah Tahun 2014. Semarang: Dinas Kesehatan.

Dinas Kesehatan Boyolali. (2014). Profil Kesehatan Kabupaten Boyolali Tahun 2014. Boyolali: Dinas Kesehatan.

Feriyanto, N. (2014). Ekonomi Sumber Daya Manusia. Yogyakarta: UPP STIM YKPN.

Fikawati, S., \& Syafiq, A. (2009). Penyebab Keberhasilan dan Kegagalan Praktik Pemberian ASI Eksklusif. Kesmas, Jurnal Kesehatan Masyarakat Nasional, 4(3), 120-131.

Gibson, J. L. (2003). Struktur Organisasi dan Manajemen. Jakarta:

Hidayat, A. (2008). Metode Penelitian Keperawatan dan Teknik Analisis Data. Jakarta Selatan: Salemba Medika.

Jalaluddin. (2013). Filsafat Ilmu Pengetahuan. Jakarta: Rajawali Pers.

Khanal, V., Lourenca, J., Brites, N., Karkee, R., \& Lee, A. H. (2014). Factors Associated with Exclusive Breastfeeding in Timor-Leste: Findings from Demographic and Health Survey 2009-2010. Nutrients, 6, 1691-1700.

Kementerian Kesehatan RI. (2014). Situasi dan Analisis ASI Ekslusif. Jakarta: Infodatin.

Maritalia, D. (2012). Asuhan Kebidanan: Nifas dan Menyusui (1st ed.). Yogyakarta: Pustaka Pelajar.

Marmi, \& Rahardjo, K. (2012). Asuhan Neonatus, Bayi, Balita, dan Anak Prasekolah. Yogyakarta: Pustaka Pelajar.

Mudzengerere, E. T., \& Mudzengerere, F. H. (2013). The Factors That Determine Exclusive Breastfeeding Amongst Babies Below Six Months Old At Chitungwiza Central Hospital In Zimbabwe. International Journal of Politics and Good Governance, 4(4), 1-19.

Naanyu, V. (2008). Young Mothers, First Time Parenthood and Exclusive Breastfeeding in Kenya. African Journal of Reproductive Health, 12(3), 125- 138.

Notoatmodjo, S. (2010). Metodologi Penelitian Kesehatan. Jakarta: Rineka Cipta.

Okawary, O. (2015). Hubungan Status Pekerjaan Ibu dengan Pemberian ASI Eksklusif di Wilayah Kerja Puskesmas Seyegan Sleman Yogyakarta. Sekolah Tinggi Ilmu Kesehatan 'Aisyiyah.

Purwanti, H. S. (2004). Konsep Penerapan ASI Eksklusif. EGC: Jakarta.

Rachmaniah, N. (2014). Hubungan Tingkat Pengetahuan Ibu tentang ASI dengan Tindakan ASI Eksklusif. Universitas Muhammadiyah Surakarta.

Riksani, R. (2012). Keajaiban ASI (Air Susu Ibu). Jakarta: Dunia Sehat.

Satino, \& Setyorini, Y. (2014). Analisis Faktor yang Mempengaruhi Pemberian ASI Eksklusif pada Ibu Primipara Di Kota Surakarta. Jurnal Terpadu Ilmu Kesehatan, 3(2), 125-130.

Suhartono, Suparlan. (2010). Filsafat Ilmu Pengetahuan: Persoalan Eksistensi dan Hakikat Ilmu Pengetahuan. Jogjakarta: Ar-Ruzz Media.

Sumantri, A. (2011). Metodologi Penelitian Kesehatan. Jakarta: Kencana. Sunyoto, D. (2011). Analisis untuk Penelitian Kesehatan. Yogyakarta: Nuha Medika.

Uchenna, O. (2012). Problems Encountered by Breastfeeding Mothers in Their Practice of Exclusive Breast Feeding in Tertiary Hospitals in Enugu State, South-East Nigeria. International Journal of Nutrition and Metabolism, 4(8), 107-113.

Wawan, A., \& Dewi, N. (2010). Teori dan Pengukuran Pengetahuan, Sikap, dan Perilaku Manusia. Yogyakarta: Nuha Medika.

WHO. (2012). Infans exclusively breastfed for the first 6 months of life. Retrieved October 24, 2015, from http://www.who.int/en 